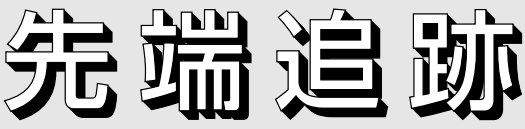

\section{［R-487］量子ドット増感太陽電池の最近の進 展}

量子ドット増感太陽電池（Quantum Dot Sensitized Solar Cell, QDSC) ${ }^{1)}$ は, 半導体量子ドットの多様な性質, たとえば, チューナブルなバンドギャップや高い吸光倸 数, 高エネルギーで励起した際の多重電子キャリア発生 などを生かすことを期待されている次世代太陽電池であ る。QDSC の基本構成は色素増感太陽電池 (DSSC) と 同様であり, 透明酸化物電極上の $\mathrm{TiO}_{2}$ 薄膜の上に, 色 素の代わりに $\mathrm{CdSe}$ などの狭いバンドギャップの半導体 ナノ結晶を付着させ, ここで光励起された電子が $\mathrm{TiO}_{2}$ に注入される。対極と電解質溶液の選択も重要である。 現状では, $11 \%$ 以上の光電変換効率が報告されている DSSC に比べて，低い值に留まっており，実用化の目処 を見極める上でも, 光電変換効率 $5 \%$ 以上の達成が望ま れていたところである。Kamatのグループは，量子ドッ トに $\mathrm{Mn}^{2+}$ をドープすることで得られるミッドギャップ 領域のドーパント由来のエネルギー準位が，他の軌道へ の遷移は禁制となるために, 長寿命を示すことに着目 し, QDSC の光電変換効率の増大を実現させた ${ }^{2)}$ 。電極 の作成は SILAR 法に基づき, FTO 電極上の $\mathrm{TiO}_{2}$ 薄膜上 に Mnをドープした CdS 層を付着させた上に, CdSe 層 を付着させた場合で, 開放電圧 $558 \mathrm{mV}$, 光電変換効率 5.42\%を実現した。また， 2 時間にわたり安定に動作す ることを示した。Mn ドープに由来する長寿命のミッド ギャプ準位に励起電子がトラップされることで，ホール や電解質の酸化されたポリスルフィドイオンとの再結合 が妨げられることで高性能が害現したと考えられてお り，今後も一層の進展が期待される。

\section{文献}

1) P.V. Kamat et al. : Chem. Rev. 110, 6664 (2010).

2) P.K. Santra and P.V. Kamat: J. Am. Chem. Soc. 134, 2508 (2012).

(東京大学 佐々木岳彦)

\section{[R-488］半導体再構成表面の高精度摩擦力顕 微鏡測定}

微小な摩擦力を制御・観察するナノトライボロジーの 最近の急速な発展を後押ししている大きな要因の一つと して, 摩擦力顕微鏡 (Friction force microscopy : FFM) 技術の著しい発展があげられる。1987 年, Mate ${ }^{11}$ が FFM でグラファイト表面の原子スケール摩擦を観察し て以来，層状物質，イオン結晶，金属など様々な試料表 面上で FFM 探針のスティック・スリップ運動や表面超 構造の摇らぎが原子スケールで観察され, 摩擦の素過程 の理解が進んでいる。一方, 半導体再構成表面の原子ス ケール摩擦の観察に完全に成功した例は多くない。たと えば 1995 年, Howald ら²) ${ }^{2}$ Si (111) $7 \times 7$ 再構成表面の 観察を行い, 摩擦力像からアダトムの間隔を評価した が, 完全な原子分解能は得られなかった。当時は, 半導 体再構成表面構造の興味深い動力学が, 飛躍的に発展し た動的原子間力顕微鏡によって次々解明されている時期 だったので，FFM 測定を高精度で行うモチベーション が上がらなかったようにも思える。

最近, Goryl ら ${ }^{3)}$ は超高真空条件下で $\operatorname{InSb}(001), \mathrm{Ge}$ (001) 再構成表面の原子スケール水平力の観察に成功し た。Si 探針で観察した $\mathrm{InSb}(001)-\mathrm{c}(8 \times 2)$ 構造には二つ の異なるドメイン構造が現れ, 各ドメイン構造は Tomlinson モデルでうまく再現された。また $(1 \times 3)$ 構造内 部には, In 原子の欠陥構造が多数観察された。これら の摩擦力像の原子分解能は荷重増加に伴い消失した。一 方ダイヤモンド探針で観察された Ge (001) 表面の摩擦力 像には $(2 \times 1)$ 構造由来と思われる特徴的なパターンが 現れた。しかしユニットセル内部の正確な原子配列を決 めることはできず，その理由として探針が原子スケール の鋭さを持っていないためであることが挙げられてい る。

以上述べた半導体再構成表面の摩擦力測定には, 垂直 方向の大きな凹凸と, 水平面内の構造異方性が深くかか わっているため, これまでの比較的平坦な表面の摩擦力 測定では得られなかった情報が引き出すことができるた め, ナノトライボロジーの新たな発展が期待される。

\section{文献}

1) C.M. Mate et al. : Phys. Rev. Lett. 59, 1942 (1987).

2) L. Howald et al. : Phys. Rev. B51, 5484 (1995).

3) M. Goryl et al. : Phys. Rev. B85, 085308 (2012). (成蹊大学 佐々木成朗) 